\title{
Poecilocampa alpina (Frey \& Wullschlegel, 1874) (Lepidoptera, Lasiocampidae), first record for Romania
}

\author{
Geanina M. Iacob, Cosmin O. Manci, Cristina Craioveanu, László Rákosy \& Cristian Sitar
}

\begin{abstract}
Summary: Poecilocampa alpina (Frey \& Wullschlegel, 1874) is reported for the first time in the Romanian fauna. The specimen was collected from Porumbenii Mari, Harghita County, Romania. According to the distribution area, respectively to the ecological requirements, the Romanian population belongs to the subspecies $P$. alpina canensis. This reported population is currently the easternmost known population of this species.
\end{abstract}

Key words: Poecilocampa alpina, Lepidoptera, Lasiocampidae, first record, Romania.

\section{Introduction}

The genus Poecilocampa (Lepidoptera, Lasiocampidae) is very well represented in the Palearctic region, less in the south of the region, where it is found locally in high mountain areas (ZoLOTUHIN 2010). In Romania, only Poecilocampa populi has been reported so far (RÁKosY et al. 2003).

Recent reports from Bulgaria (HRISTOVA and BESHKov 2016) and Albania (BeSHKov and NAHIRNIĆ 2020) of $P$. alpina and from the Timok river region (Serbia, near the border with Romania) (ZEČEvić 2002) have led to the hypothesis that Poecilocampa alpina could also be present in the Romanian fauna.

From the point of view of the taxonomic classification, the status of the species Poecilocampa alpina is controversial. In 2006, LERAUT suggested that the taxon has to be a subspecies of $P$. populi, but later in 2013 HuEMER contradicted his claims. Two subspecies of $P$. alpina have been described: P. alpina alpina (Frey \& WULLSCHLEGEL, 1874) and P. alpina canensis (MILLIÉRE, 1876).

According to the distribution area, respectively to the ecological requirements (DE FrEINA and WITT 1987), the subspecies $P$. alpina canensis should be present in Romania.

\section{Distribution}

Poecilocampa alpina is a European species, reported from the southern half of Europe.

Subspecies $P$. alpina alpina is present in the Alps and it has been reported from Italy (South Tyrol, Upper Venosta Valley), Switzerland (Valais, Goppenstein), Germany (Bavaria, Brünnstein), and Austria (East
Tyrol, Ainet; Tirol, Lermoos) (http://lepiforum. org/wiki/page/Poecilocampa Alpina, accessed at 13/07/2021, 11:46 AM).

Subspecies $P$. alpina canensis is present in central and southern Spain (DE FreINA and WITT 1987), southeastern France (Valloire, N 45.10, E 6.40) (DE Freina and WitT 1987, Fournier 2019) and also reported from northeastern, central and southern Italy, including Sicily (BERTACCINI et al. 1994).

In the Balkan Peninsula, $P$. alpina canensis has been reported in several countries. In Bulgaria, the subspecies is known from a small number of localities, all of them situated in the western part of the country (Hristova and BeshKov 2016). In Albania, the species is very well represented (BESHKOv and NAHIRNiĆ 2020) and has been reported from the localities: Pepellash Village (980 m, N 40.47, E 20.67), between Leskovik and Carshove Village (448 m, N 40.15, E 20.57) and between Mal Çajup and Erind Village (1015 m, N 40.18, E 20.17) (BeshKov and NAHIRNić 2020). In Croatia, it has been recorded only from Biokovo and southern Dalmatia (https://biologer.hr/ groups/18/species/719 accessed at: 12/07/2021, 2:37 PM). In Serbia, confirmed reports are from Timok (ZeĆEvić 2002) and Starac (BESHKov and NAHIRNiĆ 2016).

\section{Material and methods}

The first individual (a male) from Romania was collected on 12.11.2017 from Porumbenii Mari, Harghita County (800 m, N 46.30, E 25.16) (fig. 1). The specimen was captured using a light trap. The light sources were fluorescent $\mathrm{Hg}$ vapour lamps $(2 \mathrm{x}$ $160 \mathrm{~W})$ and UV black light lamps (2 x $18 \mathrm{~W})$. 


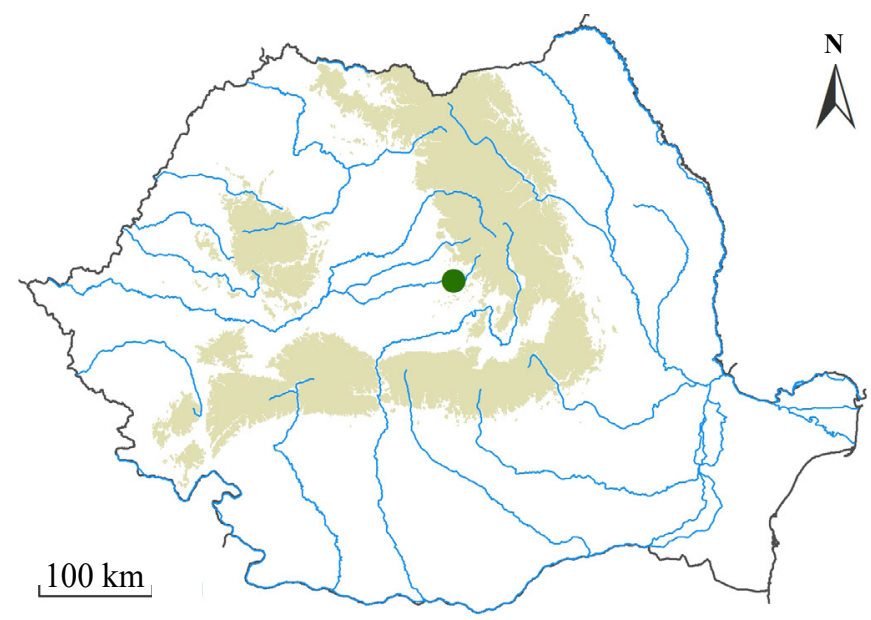

Fig. 1. Map of the location where the specimen was collected (green dot: Porumbenii Mari, Harghita county).

The habitat in the area is mixed forest with different species of Quercus, Fagus, Carpinus, Populus and Crataegus and Juniperus at the edge (fig. 2). The light trap was placed at the edge of the forest.

The specimen was identified using standard works (DE FreInA and WitT 1987, ZoLOTUHIN and Saldaitis 2010, Segerer and Hausman 2011, STEINER et al. 2014) and for safety we have also examined the specimen's genitalia and compared it with LERAUT (2006).

Genitalia of $P$. alpina were dissected using conventional procedures (FIBIGER 1997). Male abdomina were boiled in $10 \%$ caustic potash. The genitalia were cleaned from surrounding tissues and the aedeagus was removed. Genital slides were photographed using an Optikam Pro HDMI digital camera mounted on an Optika ZSN-2 stereomicroscope. The specimen is deposited in the collection of Cristian SITAR.

\section{Diagnosis}

Poecilocampa alpina can be recognized by the light grey edge of the forewing (fig. 3). The base color of $P$. alpina is grey-black. The outer transverse band of the forewing is sharp, clearly developed and the outer submarginal field is whitish-grey sprinkled with dark grey scales. The middle field of the forewing is dark grey, the color of the basal field of the forewing is from light brown to yellow, being clearly highlighted. The outer half of the hind wing is grey-whitish. The inner half is darker grey sprinkled with light brown to yellow hairs. The variability of $P$. alpina specimens is extremely high, which led to the unnecessary description of a number of taxa.

Between P. alpina and P. populi, there are visible

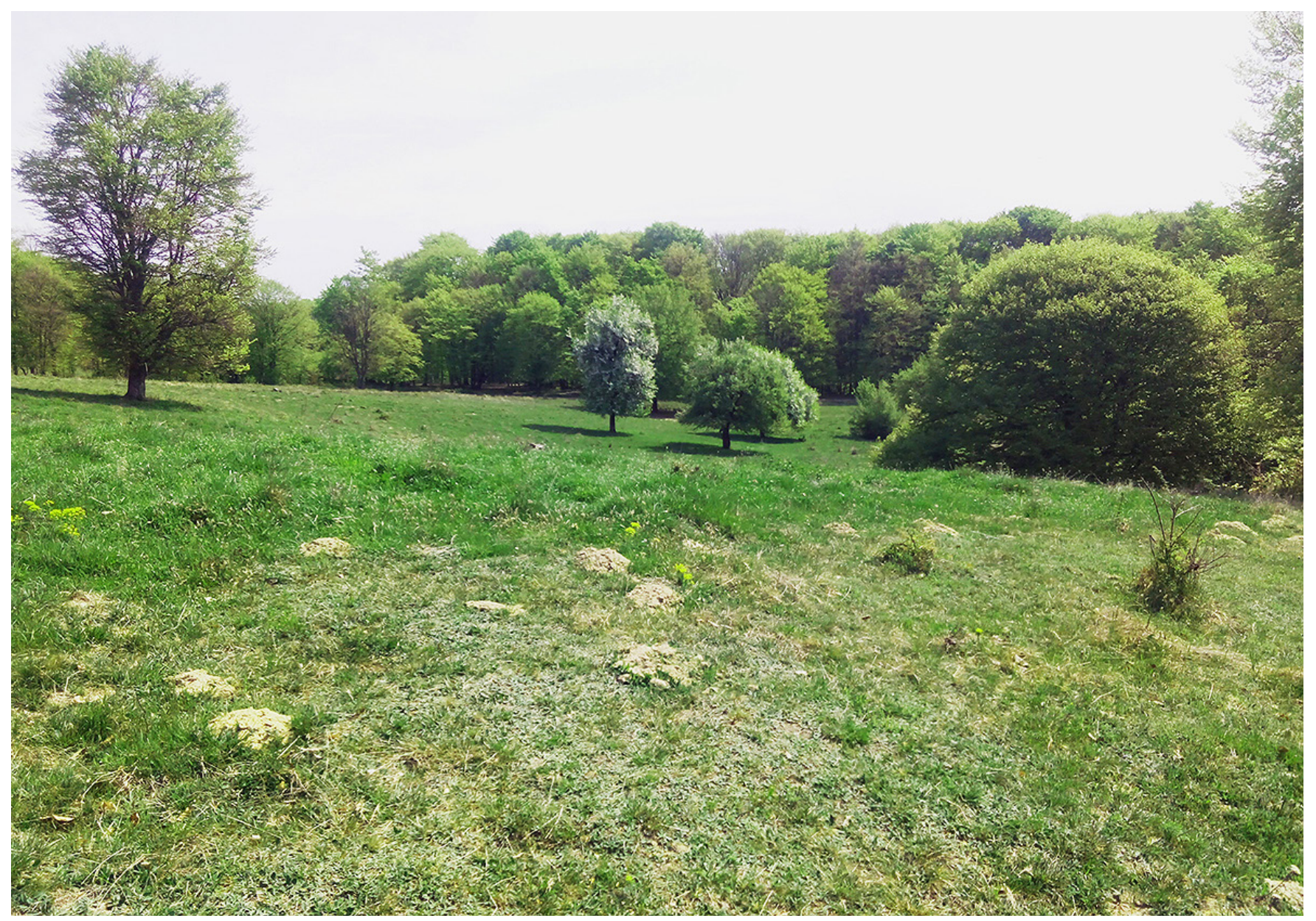

Fig. 2. Habitat where the specimen was collected, near Porumbenii Mari, Harghita County. The habitat is a mixed forest with Quercus sp., Fagus sp., Carpinus sp. and Populus sp. In its vicinity there are meadows with Crataegus sp. and Juniperus sp. shrubs. 
differences at the level of the uncus and the aedeagus (fig. 4).

P. alpina has often been confused with $P$. populi also due to its genitalia variability (BeshKov and NAHIRNIĆ 2016).

\section{Biology and ecology}

Poecilocampa alpina is part of the autumnwinter-flying moth species. P. alpina canensis was found at altitudes of $448 \mathrm{~m}$ (Balkans) (BeshKov and NAHIRNIĆ 2020) to $1800 \mathrm{~m}$ in southern France, and the subspecies $P$. alpina alpina is typical of the high areas of central Europe where it was found at over $2000 \mathrm{~m}$ (Alps) (DE Freina and WitT 1987).

P. alpina flies from late September to November, depending on altitude and weather conditions; $P$. alpina canensis was reported until January at low altitudes (DE FreINA and WITT 1987).

At high altitudes, the larvae generally feed on Larix sp., occasionally on Salix sp. or Alnus sp., and at low altitudes, they feed on Quercus sp., Prunus spinosa and Populus alba (DE FreInA and WitT 1987, BERTACCINI et al. 1994).

The early stages of $P$. alpina are little known. However, considering the phenology of the imago stage, the species probably overwinters as an egg, the larvae develop in April-June and the pupae in JuneOctober, like in the case of $P$. populi. The two species have a similar flight period and sometimes even cohabit (PoIVRe 1986).

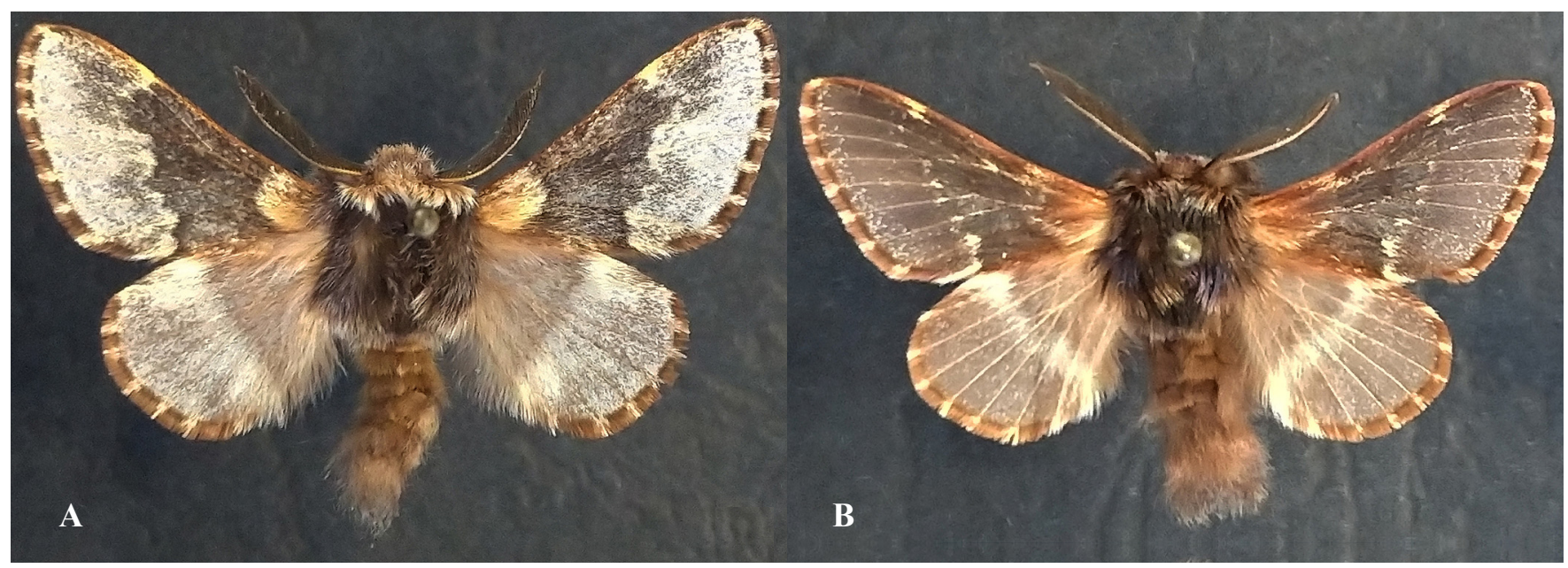

Fig. 3. A. Poecilocampa alpina male collected near Porumbenii Mari, Harghita County; B. Poecilocampa populi male, collected near Porumbenii Mari, Harghita County.
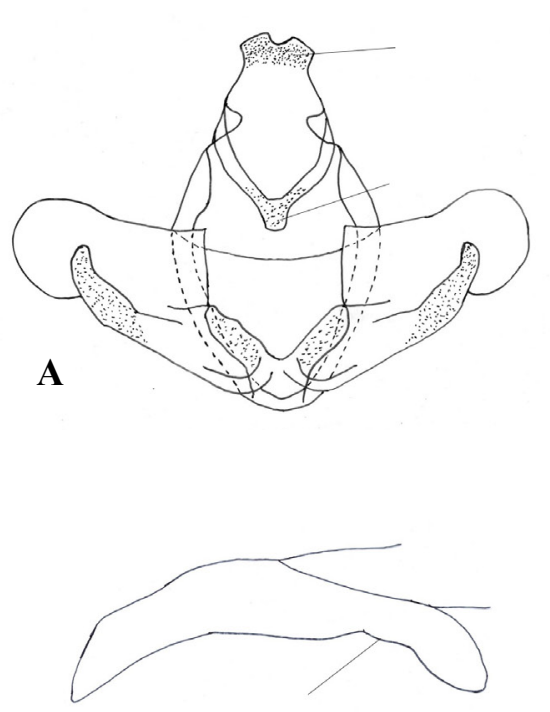

C
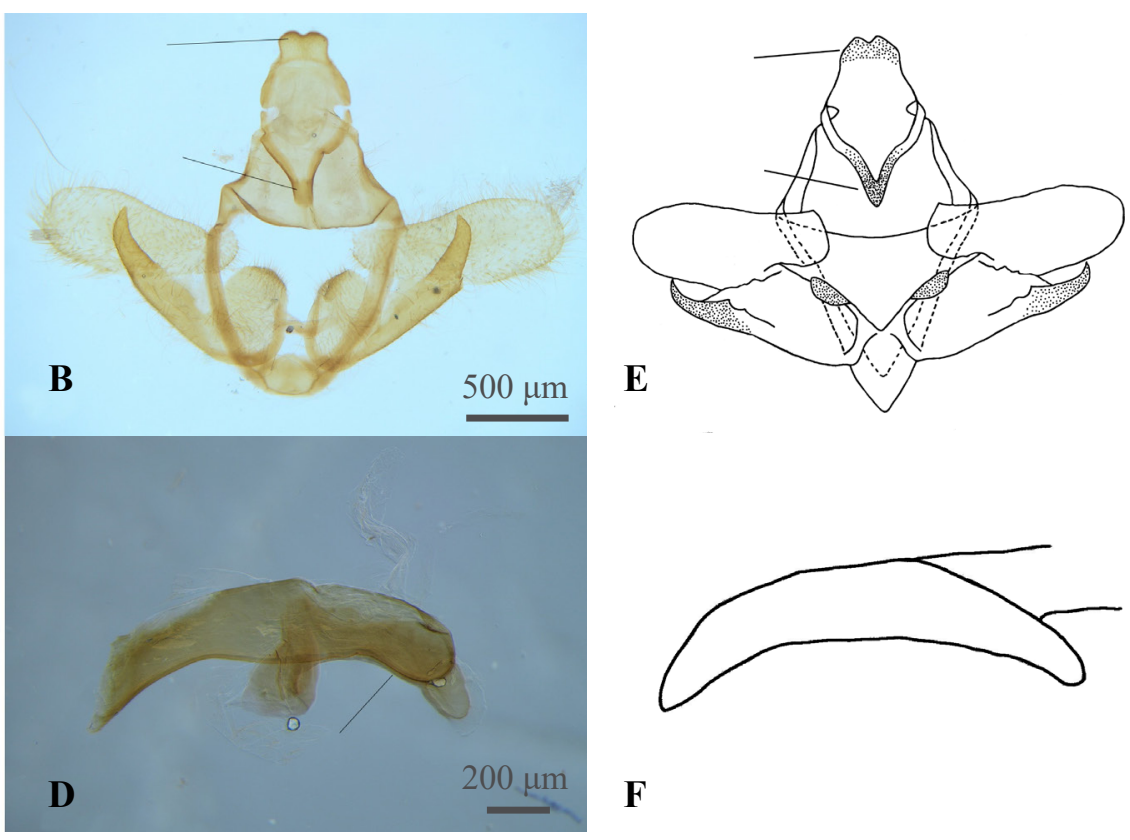

$\mathbf{F}$

Fig. 4. Genitalia: A. Schematic representation of the genital armature of P. alpina canensis after LERAUT (2006); B. The genital armature of the specimen collected near Porumbenii Mari, Harghita County; C. Aedeagus of P. alpina canensis, schematic representation after Leraut (2006); D. Aedeagus of the specimen collected near Porumbenii Mari, Harghita County; E. Schematic representation of the genital armature of P. populi after LeraUt (2006); F. Aedeagus of P. populi, schematic representation after LERAUT (2006). 


\section{Conclusions}

The presence of $P$. alpina is reported so late in the Romanian fauna due to the few entomological researches. The main problem in detecting the species is its late flight period, when most entomologists stop their field activities. P. alpina is a species that needs more attention from lepidopterists, because most likely the species is also present in other regions of the country.

The population of P. alpina we found in Romania is currently the easternmost known population of this species.

\section{Acknowledgements}

This work was funded by Babeș-Bolyai University through the Special research scholarship awarded to Geanina-Magdalena Iacob. The authors are grateful to Andrei Crișan for the help with figure 1.

\section{References}

Bertaccini E., Fiumi G. and Provera P. (1994) Bombici e Sfingi d'Italia (Lepidoptera Heterocera) vol. I. NaturaGiuliano Russo, Monterenzino, 247 pp.

BeshKov S. and NAHIRNić A. (2016) New and rare nocturnal Lepidoptera species for Serbia from Preševo District and Pčinja River Valley-hot spots for biodiversity. Atalanta (Marktleuthen) 47(1/2): 139-149.

Beshkov S. and Nahirnić A. (2020) Contribution to knowledge of the Balkan Lepidoptera (Lepidoptera: Macrolepidoptera). Ecologica Montenegrina 30: 1-27.

DE FreinA J.J. and Witt T.J. (1987) Die Bombyces und Sphinges der Westpalaearktis: Insecta, Lepidoptera. Bd 2. Ed. Forschung \& Wissenschaft.

Fibiger M. (1997) Noctuinae III. Noctuidae Europaeae. Entomological Press, Sorø.

FOURNIER F.N., Inventaire National du Patrimoine Naturel
(2019). Données Lépidoptères du cadre d'acquisition de François Fournier. Version 1.1. UMS PatriNat (OFBCNRS-MNHN), Paris. Occurrence dataset https://doi. org/10.15468/2ffp0r accessed via GBIF.org on 202107-13. https://www.gbif.org/occurrence/2475313506.

Hristova H. and BeshKov S. (2016) Checklist of the Superfamilies Cossoidea, Thyridoidea, Drepanoidea, Lasiocampoidea, Bombycoidea and Noctuoidea: Notodontidae (Insecta: Lepidoptera) of Bulgaria, with Application of the IUCN Red List Criteria at the National Level. Acta zoologica bulgarica 68(4): 569-576.

Huemer P. (2013) Die Schmetterlinge Österreichs (Lepidoptera): systematische und faunistische Checkliste. Innsbruck: Tiroler Landesmuseen.

Leraut P. (2006) Papillons de nuit d'Europe: Bombyx, Sphinx, Ecailles. NAP.

Poivre R. (1986) Note sur la présence de Poecilocampa alpina Frey et Wullschlegel dans les Hautes-Alpes et sa cohabitation avec Poecilocampa populi Linné (Lep. Lasiocampidae). Alexanor 14 (6): 281-282.

RÁkosy L., GoIA M. and Kovács Z. (2003) Catalogul Lepidopterelor României/Verzeichnis der Schmetterlinge Rumäniens. Societatea Lepidopterologică Română, Cluj-Napoca, 446.

Segerer A.H. and Hausman A. (2011) The Macrolepidoptera of Germany, Heterocera Press.

Steiner A., Ratzei U., Tom-Jensen M. and Fibiger M. (2014) Die Nachtfalter Deutschlands. Ein Feldführer. BugBook Publishing.

ZEČEVIĆ M. (2002). Fauna Leptira Timocke Krajne (Istočna Srbija). - DSIP „BAKAR“ BOR, Narodni Muzej Zaječar, Zaječar

Zolotuhin V.V. and SAldaitis A. (2010) Two new mountain species of the genus Poecilocampa STEPHENS, 1828 (Lasiocampidae). Tinea 21(2): 88-94, accessed at 13/07/2021, 11:46 AM.

https://biologer.hr/groups/18/species/719 accessed at: 12/07/2021, 2:37 PM.

http://lepiforum.org/wiki/page/Poecilocampa_Alpina, accessed at 13/07/2021, 11:46 AM.
Geanina Magdalena IACOB Department of Taxonomy and Ecology Babeș-Bolyai University, Clinicilor 5-7 Cluj-Napoca, 400006, Romania E-mail: giacob@yahoo.com

László RÁKOSY

Department of Taxonomy and Ecology Babes-Bolyai University, Clinicilor 5-7 Cluj-Napoca, RO-400006, Romania E-mail: laszlo.rakosy@ubbcluj.ro
Cosmin O. MANCI

Oceanographic Research and Marine

Environment Protection Society

Oceanic-Club, Decebal 41,

Constanta, Romania

E-mail:cosminom@gmail.com

Cristian SitaR

Department of Taxonomy and Ecology Babes-Bolyai University, Clinicilor 5-7

Cluj-Napoca, 400006, Romania

Zoological Museum

Babeș-Bolyai University, Clinicilor 5-7

Cluj-Napoca, RO-400006, Romania

E-mail: cristiansitar@yahoo.com
Cristina Craioveanu

Department of Taxonomy and Ecology Babeș-Bolyai University, Clinicilor 5-7 Cluj-Napoca, 400006, Romania

E-mail: cristinacraioveanu@gmail.com

Received: 01.08.2021

Accepted: 01.10.2021

Published online: 31.12 .2021

Article number: ER25202102

doi: 10.24193/entomolrom.25.2 